\title{
Natural new particle formation at the coastal Antarctic site Neumayer
}

\author{
R. Weller ${ }^{1}$, K. Schmidt ${ }^{1}$, K. Teinilä ${ }^{2}$, and R. Hillamo ${ }^{2}$ \\ ${ }^{1}$ Alfred Wegener Institute for Polar and Marine Research, Am Handelshafen 12, 27570 Bremerhaven, Germany \\ ${ }^{2}$ Finnish Meteorological Institute, Erik Palménin aukio 1, 00101 Helsinki, Finland \\ Correspondence to: R. Weller (rolf.weller@awi.de)
}

Received: 25 March 2015 - Published in Atmos. Chem. Phys. Discuss.: 11 June 2015

Revised: 6 October 2015 - Accepted: 6 October 2015 - Published: 15 October 2015

\begin{abstract}
We measured condensation particle (CP) concentrations and particle size distributions at the coastal Antarctic station Neumayer $\left(70^{\circ} 39^{\prime} \mathrm{S}, 8^{\circ} 15^{\prime} \mathrm{W}\right)$ during two summer campaigns (from 20 January to 26 March 2012 and 1 February to 30 April 2014) and during the polar night between 12 August and 27 September 2014 in the particle diameter $\left(D_{\mathrm{p}}\right)$ range from 2.94 to $60.4 \mathrm{~nm}(2012)$ and from 6.26 to $212.9 \mathrm{~nm}$ (2014). During both summer campaigns we identified all in all 44 new particle formation (NPF) events. From 10 NPF events, particle growth rates could be determined to be around $0.90 \pm 0.46 \mathrm{~nm} \mathrm{~h}^{-1}$ (mean $\pm \mathrm{SD}$; range: $0.4-1.9 \mathrm{~nm} \mathrm{~h}^{-1}$ ). With the exception of one case, particle growth was generally restricted to the nucleation mode $\left(D_{\mathrm{p}}<25 \mathrm{~nm}\right)$ and the duration of NPF events was typically around $6.0 \pm 1.5 \mathrm{~h}$ (mean $\pm \mathrm{SD}$; range: $4-9 \mathrm{~h}$ ). Thus, in the surrounding area of Neumayer, particles did not grow up to sizes required for acting as cloud condensation nuclei. NPF during summer usually occurred in the afternoon in coherence with local photochemistry. During winter, two NPF events could be detected, though showing no ascertainable particle growth. A simple estimation indicated that apart from sulfuric acid, the derived growth rates required other low volatile precursor vapours.
\end{abstract}

\section{Introduction}

The crucial role of aerosols as a key component in governing radiation transfer through Earth's atmosphere, and thus their pivotal role in determining climate, has boosted aerosol research activities and strongly promoted our knowledge on this topic. Their relevance in climate forcing is most no- tably evident since they potentially act as condensation nuclei for cloud droplets, thus influencing radiation transfer indirectly (Haywood and Boucher, 2000; Ramanathan et al., 2001; Carslaw et al., 2013; Rosenfeld et al., 2014). In particular due to the latter effect, involving inherently complicated feedback mechanisms, aerosols still notoriously contribute to the largest uncertainty in estimating climate forcing (for a comprehensive treatise we refer to Boucher et al., 2013, and references therein).

One focus of interest in aerosol research is dedicated to questions regarding new particle formation (NPF), the dominant global particle source generating so-called secondary aerosol (Spracklen et al., 2006). This process starts with the nucleation of gaseous precursors to molecular clusters (Zhang et al., 2012) followed by particle growth to sizes potentially relevant for acting as cloud condensation nuclei (CCN; Spracklen et al., 2008; Bzdek and Johnston, 2010).

Recent research activities documented the global importance of natural secondary aerosol from the marine atmosphere and revealed that apart from dimethyl sulfide (DMS)derived sulfuric acid $\left(\mathrm{H}_{2} \mathrm{SO}_{4}\right)$, especially marine volatile organic compounds (VOCs) but also reactive iodine species mediate particle nucleation and growth (O'Dowd et al., 2002a, b; Henze and Seinfeld, 2006; O'Dowd and de Leeuw, 2007; Facchini et al., 2008a; McFiggans et al., 2010). Notably, in terms of secondary aerosol formation, the virtually completely ice-covered and thus effectively sourcefree Antarctic continent represents an outstanding case: surrounded and isolated by the Southern Ocean from other continents, NPF should be inherently linked with the advection of marine air masses. Apart from some earlier work reporting on the frequent occurrence of bimodal particle size distribu- 
tions below $100 \mathrm{~nm}$ in coastal Antarctica (Ito, 1985, 1993; Jaenicke et al., 1992), NPF has been recently described for several Antarctic sites. Most extensive measurements were conducted at the Finnish station Aboa $\left(73^{\circ} 03^{\prime} \mathrm{S}, 13^{\circ} 25^{\prime} \mathrm{W}\right.$, $496 \mathrm{~m}$ a.s.1.), located on a nunatuk about $130 \mathrm{~km}$ from the sea (Koponen et al., 2003; Asmi et al., 2010; Kyrö et al., 2013). Asmi et al. (2010) reported on NPF events showing growth rates (GRs) within the nucleation mode between 0.8 and $2.5 \mathrm{~nm} \mathrm{~h}^{-1}$, while in a subsequent summer campaign, significantly higher GRs between 1.8 and $8.8 \mathrm{~nm} \mathrm{~h}^{-1}$ were found and particle growth usually extended well into the Aitken mode (Kyrö et al., 2013). A thorough data analysis by Kyrö et al. (2013) revealed that most probably biogenic precursors originating from local melting ponds provided low volatile vapour needed for the observed particle growth. Hence, this study was the first one indicating that (biogenic) emissions from continental Antarctic could be a source for secondary aerosol formation and relativized the source-free character of continental Antarctica. Regarding the Antarctic Plateau, NPF events reported from the South Pole were ascribed to local contamination (Park et al., 2004). In contrast, during year-round measurements at Dome $\mathrm{C}\left(75^{\circ} 06^{\prime} \mathrm{S}\right.$, $123^{\circ} 23^{\prime}$ E, 3200 m a.s.1.), several NPF events could be observed throughout the year, mostly associated with particle growth starting from the nucleation into the Aitken mode (Järvinen et al., 2013). Most surprisingly, growth rates tentatively appeared even higher compared to Aboa (median considering all events: $2.5 \mathrm{~nm} \mathrm{~h}^{-1}$, range: $0.5-14.1 \mathrm{~nm} \mathrm{~h}^{-1}$; Järvinen et al., 2013). Finally a recent ship-borne study indicated a $\mathrm{Hg}$ driven nucleation event over east Antarctic sea ice (Humphries et al., 2015). Complementary to these local field investigations, dedicated modelling studies can give spatially inclusive and comprehensive insights regarding sources and mechanisms of NPF and the influence on CCN concentrations in the remote atmosphere of the Southern Ocean. The work of Korhonen et al. (2008) revealed a weaker impact of DMS-derived secondary aerosol on marine CCN concentrations at high southern latitudes, largely caused by much stronger sea spray emissions south of $45^{\circ} \mathrm{S}$. This study also emphasized the importance of NPF in the free troposphere followed by particle growth during entrainment into the marine boundary layer. The Yu and Luo (2010) investigations targeted the modelling DMS-derived NPF around coastal Antarctica and demonstrated that ion-mediated nucleation can reasonably predict the observed seasonality of condensation particle (CP) concentrations at coastal Antarctica.

Our present work ties in with a previous publication that examined the climatology of $\mathrm{CP}$ concentrations at the German Antarctic research station Neumayer (Weller et al., 2011a). This precedent study indicated the importance of particle nucleation occurring even during late winter and early spring in determining particle number concentrations. In the current study we will entirely focus on the dynamics of particle size distribution and NPF, relying on two dedicated summer campaigns in 2012 and 2014, as well as a measuring period during austral winter (August and September 2014).

\section{Experimental techniques and data evaluation methods}

\subsection{Site description and instrumentation}

All experiments were conducted inside the Air Chemistry Observatory located close to Neumayer Station (NM, $70^{\circ} 39^{\prime} \mathrm{S}, \quad 8^{\circ} 15^{\prime} \mathrm{W}, \quad$ http://www.awi.de/en/science/ long-term-observations/atmosphere/antarctic-neumayer/ air-chemistry.html, last access: 1 October 2015). Measuring site, prevailing local meteorological conditions, characteristics of the air inlet system and, finally, aspects of contamination-free sampling have already been described in some detail and we refer to König-Langlo et al. (1998) and Weller et al. (2011a and references therein).

The size distribution of the sub-micrometre aerosol at NM was determined by a scanning mobility particle sizer (SMPS, TSI classifier model 3080; Wang and Flagan, 1990). During austral summer 2012, i.e. from 20 January to 26 March, the classifier was operated with a so-called nano-DMA (nano differential mobility analyser, TSI Model 3085) in combination with a condensation particle counter (CPC, TSI model WCPC $3788,50 \%$ cut-off diameter $D_{\mathrm{p}(50 \%)}$ of $\left.2.5 \mathrm{~nm}\right)$. We adjusted aerosol and sheath flow to achieve nominal aerosol size distribution measurements between 2 and $64 \mathrm{~nm}$ with a 64 channel resolution. Note that the SMPS primarily measured the electrical mobility of particles which was finally converted by a known transfer function to the corresponding particle mobility diameter $D_{\mathrm{p}}$. Due to increased uncertainty caused by diffusional losses and cut-off corrections for the used CPC, we evaluated the data starting from $3 \mathrm{~nm}$. All size spectra were multiple-charge and diffusion-corrected according to the TSI software AIM (Aerosol Instrument Manager $\left.{ }^{\circledR}\right)$. The original spectra were taken with a scanning time of $120 \mathrm{~s}$ (retrace time $15 \mathrm{~s}$ ) and the average size distribution of four consecutive spectra was stored for further evaluation, resulting in a temporal resolution of $600 \mathrm{~s}$ (duty cycle 480 s). During 2014 the measuring period was from 1 February to 30 April and from 12 August to 27 September. Due to technical problems we could not run the SMPS with the same configuration as in 2012 but used here a DMA model 3081 in combination with a CPC $3025 \mathrm{~A}$ (TSI, $D_{\mathrm{p}(50 \%)}$ of $3 \mathrm{~nm}$ ). Now, the air flow ratio was adjusted to enable size distribution measurements in the range between 6 and $213 \mathrm{~nm}$. Note that due to the geometry of the DMA 3081, inherently longer particle residence time entailed perceptible particle losses resulting in enhanced uncertainties in the size distribution below $10 \mathrm{~nm}$ (according to the manufacturer, uncertainties in the size range between 10 and $6 \mathrm{~nm}$ could be about a factor of 1.5-2 higher for the DMA 3081 compared to the DMA 3085). As in Dal Maso et al. (2005), we will use the terms 
nucleation mode for particles with $D_{\mathrm{p}}<25 \mathrm{~nm}$ and Aitken mode for the size range $25 \mathrm{~nm} \leq D_{\mathrm{p}}<100 \mathrm{~nm}$ throughout the text.

Particle size distributions were evaluated along with continuous long-term CP concentration measurements (CPC 3022A, TSI, $D_{\mathrm{p}(50 \%)}$ of $7 \mathrm{~nm}$ ) and the ionic composition of the aerosol. For the latter, bulk aerosol sampling was regularly conducted in $24 \mathrm{~h}$ time periods using a teflon and a nylon filter in series (all $1 \mu \mathrm{m}$ pore size). According to Piel et al. (2006) and Weller and Lampert (2008) samples were analysed by ion chromatography for methane sulfonate $\left(\mathrm{CH}_{3} \mathrm{SO}_{3}^{-}, \mathrm{MSA}^{-}\right), \mathrm{Cl}^{-}, \mathrm{Br}^{-}, \mathrm{NO}_{3}^{-}, \mathrm{SO}_{4}^{2-}, \mathrm{Na}^{+}, \mathrm{NH}_{4}^{+}, \mathrm{K}^{+}$, $\mathrm{Mg}^{2+}$, and $\mathrm{Ca}^{2+}$. In addition, aerosol light scattering measurements from a continuously operated three-wavelength integrating nephelometer (TSI, type 3563) were considered. Operation and data evaluation were explained in detail in Weller and Lampert (2008). Scattering Ångström exponents $\alpha$ were calculated according to

$\alpha\left(\lambda_{1}-\lambda_{2}\right)=\frac{\log \left(\sigma_{\mathrm{sp}}\left(\lambda_{1}\right) / \sigma_{\mathrm{sp}}\left(\lambda_{2}\right)\right)}{\log \left(\lambda_{1} / \lambda_{2}\right)}$,

where $\alpha\left(\lambda_{1}-\lambda_{2}\right)$ refers to the wavelength pair $\lambda_{1}(\mathrm{~nm})$ and $\lambda_{2}(\mathrm{~nm})$ and $\sigma_{\mathrm{sp}}(\lambda)$ are the total scattering coefficients (measured in $\mathrm{Mm}^{-1} ; 1 \mathrm{Mm}^{-1}=10^{-6} \mathrm{~m}^{-1}$ ).

Meteorological data were available from the meteorological observatory at NM (a description of the observatory itself and the installed meteorological sensors can be found at http://www.awi.de/nc/en/science/long-term-observations/ atmosphere/antarctic-neumayer/meteorology.html, last access: 1 October 2015). The origin of the advected air masses was assessed by 5-day backward trajectories provided by HYSPLIT 4.0 (Hybrid Single-Particle Lagrangian Integrated trajectory; http://www.arl.noaa.gov/documents/ reports/hysplit_user_guide.pdf, last access: 1 October 2015). For all trajectory calculations we used GDAS (Global Data Assimilation System) meteorological data with a spatial resolution of $1^{\circ} \times 1^{\circ}$ (longitude $\times$ latitude grid). HYSPLIT trajectories also provide a crude estimate of the vertical mixing height. Calculations were executed in $1 \mathrm{~h}$ time steps. The accuracy of the used 5-day back trajectories is difficult to assess (see e.g. review by Stohl, 1998). As outlined in Weller et al. (2014), above all the reliability of vertical wind components could be problematic especially for regions like the Southern Ocean with sparse meteorological input data (Harris et al., 2005). Thus, we calculated all trajectories using the 3-D wind fields of the GDAS data as well as employing the isentropic approximation. We realized in some cases horizontal differences of up to around $500 \mathrm{~km}$ between the starting points of individual 5-day back trajectories calculated either under 3-D or isentropic approximations, but the general horizontal advection characteristic on which our conclusions were finally based appeared robust. As to be expected, the vertical profile could significantly differ between both approaches and should be regarded with particular caution.
Finally, in order to specify the characteristics of the local planetary boundary layer (PBL) we additionally gauged vertical mixing in that layer as described in Weller et al. (2011a, 2014 ) by using the local bulk Richardson number $R i_{\mathrm{B}}$ (Stull, 1988).

\subsection{Data evaluation methods}

Particle concentrations, especially within the nucleation mode are susceptible to local contamination. Hence, data recorded under potential contamination conditions, indicated by wind directions within a $330^{\circ}-30^{\circ}$ sector and/or wind velocities below $2.0 \mathrm{~m} \mathrm{~s}^{-1}$, were removed. In addition, black carbon (BC) concentrations were continuously monitored by a Multi Angle Absorption Photometer (MAAP, model 5012, Thermo Electron Corp.), providing a supplemental criterion for local pollution when $\mathrm{BC}$ concentration levels exceeded $100 \mathrm{ng} \mathrm{m}^{-3}$. Potential contamination happened only very sporadically within short periods (some hours at most) and, on the whole, the actual data loss due to potential contamination was virtually negligible.

The crucial point of this study was to identify and characterize new particle formation. For this, we relied on the detailed criteria described by Dal Maso et al. (2005) and Kulmala et al. (2012). According to these recommendations, we defined a NPF event provided that particle size distribution starts within the nucleation mode $\left(D_{\mathrm{p}}<25 \mathrm{~nm}\right)$ and prevailed for more than an hour. If the recorded size distribution spectra indicated particle growth, the linear GR, defined as the change in particle diameter $\Delta D_{\mathrm{p}}(\mathrm{nm})$ during a time step $\Delta t$ (h) was determined by the so-called mode fitting method and in addition by the method of maximum concentration (Dal Maso et al., 2005; Yli-Juuti et al., 2011; Kulmala et al., 2012). We assumed that the GR was constant throughout the event and determined the GR by a linear fit through the geometric mean $D_{\mathrm{p}}$ (derived from the mode fitting procedure) at different times. In our case, nucleation mode and Aitken mode were generally well separated and log-normal distributions could be reliably fitted to the results. In contrast, the maximum concentration method resulted in somewhat higher GR compared to the mode fitting procedure (Table 1, values in parentheses). However, the latter approach was occasionally not successful, so we relied on the mode fitting method. Finally we estimated nucleation particle formation rate for the size range between 3 and $25 \mathrm{~nm}$, defined by

$J_{3-25}=\frac{\mathrm{UCP}_{3-25}}{\Delta t}$.

Here, $\mathrm{UCP}_{3-25}$ (ultrafine condensation particles) is the particle concentration in the size range between 3 and $25 \mathrm{~nm}$ derived from the SMPS data. Note that our approach to calculate particle formation as well as GR presumes a homogenous air mass and thus neglects the impact of changing air mass advection. Unfortunately, particle size distribution data were only available from 3 to $64 \mathrm{~nm}$ and 6 to 
Table 1. Nucleation events of class I (Dal Maso et al., 2005) during the austral summers of 2012 and 2014: Time period during which the particle growth in the given range was observed, growth rate determined by log-normal mode fitting and maximum concentration (in parentheses) method, particle formation rate in the size range 3-25 nm ( $\left.\mathrm{J}_{3-25}\right)$, and estimated $\mathrm{H}_{2} \mathrm{SO}_{4}$ vapour concentration needed for the observed growth rate.

\begin{tabular}{|c|c|c|c|c|c|}
\hline Date (doy 2012) & Time period & $\begin{array}{l}\text { Growth rate } \\
\qquad\left(\mathrm{nm} \mathrm{h}^{-1}\right)\end{array}$ & $\begin{array}{r}\text { Range } \\
(\mathrm{nm})\end{array}$ & $\left(\mathrm{cm}^{-3} \mathrm{~s}^{\mathrm{J}_{3-25}}\right)$ & $\begin{array}{r}\mathrm{H}_{2} \mathrm{SO}_{4} \text { needed } \\
\left(\text { molec } \mathrm{cm}^{-3}\right)\end{array}$ \\
\hline \multirow[t]{2}{*}{27 Jan 2012 (27) } & 07:00-14:00 & $1.9 \pm 0.1(2.5 \pm 0.3)$ & $18.7-33.7$ & $0.1 \pm 0.05$ & $3.7 \times 10^{7}$ \\
\hline & 11:00-18:00 & $1.8 \pm 0.1(2.1 \pm 0.3)$ & $6.8-20.2$ & n.d. ${ }^{\mathrm{a}}$ & $3.3 \times 10^{7}$ \\
\hline 23 Feb 2012 (54) & $12: 00-18: 00$ & $0.6 \pm 0.07$ (n.d.) & $4.9-8.9$ & $0.1 \pm 0.03$ & $1.2 \times 10^{7}$ \\
\hline 25 Feb 2012 (56) & $13: 00-17: 00$ & $0.9 \pm 0.07$ (n.d.) & $5.2-8.4$ & $0.03 \pm 0.01$ & $1.7 \times 10^{7}$ \\
\hline \multirow[t]{2}{*}{27 Feb 2012 (58) } & 11:00-18:00 & $1.0 \pm 0.05(1.1 \pm 0.2)$ & $11.6-18.5$ & $0.06 \pm 0.02$ & $1.9 \times 10^{7}$ \\
\hline & 13:00-18:00 & $0.9 \pm 0.09(1.0 \pm 0.2)$ & $5.2-9.1$ & $0.06 \pm 0.02$ & $1.9 \times 10^{7}$ \\
\hline 8 Mar 2012 (68) & 08:00-17:00 & $0.8 \pm 0.04(1.0 \pm 0.1)$ & $7.8-14.8$ & $0.02 \pm 0.01$ & $1.6 \times 10^{7}$ \\
\hline 9 Mar 2012 (69) & 14:00-19:00 & $0.8 \pm 0.08(1.4 \pm 0.3)$ & $5.2-9.1$ & $0.08 \pm 0.03$ & $1.9 \times 10^{7}$ \\
\hline \multirow[t]{2}{*}{16 Mar 2012 (76) } & 10:00-16:00 & $0.8 \pm 0.1(1.5 \pm 0.6)$ & $13.2-18.3$ & $0.07 \pm 0.02$ & $1.5 \times 10^{7}$ \\
\hline & $14: 00-21: 00$ & $1.0 \pm 0.09(1.1 \pm 0.2)$ & $5.9-12.9$ & $0.09 \pm 0.03$ & $0.9 \times 10^{7}$ \\
\hline 24 Mar 2012 (84) & $15: 00-19: 00$ & $0.5 \pm 0.05$ (n.d.) & $4.1-6.1$ & $0.02 \pm 0.01$ & $1.4 \times 10^{7}$ \\
\hline 6 Feb 2014 & $14: 00-19: 00$ & $0.4 \pm 0.2^{\mathrm{b}}$ (n.d.) & $8.8-11.3^{\mathrm{b}}$ & n.d. ${ }^{\mathrm{c}}$ & $0.8 \times 10^{7}$ \\
\hline 24 Mar 2014 & 11:00-18:00 & $0.5 \pm 0.1$ (n.d.) & $14.5-16.6$ & n.d. ${ }^{\mathrm{c}}$ & $0.9 \times 10^{7}$ \\
\hline
\end{tabular}

${ }^{a}$ n.d.: not determined; ${ }^{b}$ measured with the long DMA (TSI model 3081) with enhanced uncertainty below $10 \mathrm{~nm}$; ${ }^{\mathrm{c}}$ particle formation rate not determined due to higher cut-off of the SMPS used during this period.

$213 \mathrm{~nm}$, respectively; hence, an appropriate calculation of coagulation and condensation losses to correct GR and particle formation rate was impossible but should usually be negligible in clean, homogeneous air masses (Kulmala et al., 2004a; Leppä et al., 2011). In fact, during both campaigns, total CP concentrations measured by the CPC $3022 \mathrm{~A}$ were typically below $1000 \mathrm{~cm}^{-3}$ and only very rarely reached $2000 \mathrm{~cm}^{-3}$. In addition, during all NPF events nucleation mode particles $\left(D_{\mathrm{p}}<25 \mathrm{~nm}\right)$ constituted the major component of the total $\mathrm{CP}$ concentration. According to Leppä et al. (2011), self-coagulation and coagulation scavenging might have distorted in our case growth rates well below 0.03 and $0.02 \mathrm{~nm} \mathrm{~h}^{-1}$, respectively, corresponding to a condensation sink (CS) $<2 \times 10^{-3} \mathrm{~s}^{-1}$. Virkkula et al. (2011) estimated CS using light scattering data from nephelometer measurements. Adapting the calibration presented therein and the actually observed $\sigma_{\mathrm{sp}}(550)$ values during NPF events at NM (typically below $5 \mathrm{Mm}^{-1}$ ) indicated again a CS of around $10^{-3} \mathrm{~s}^{-1}$.

According to Nieminen et al. (2010) and Yli-Juuti et al. (2011), we finally estimated the $\mathrm{H}_{2} \mathrm{SO}_{4}$ vapour concentration needed for the calculated GR, assuming that $\mathrm{H}_{2} \mathrm{SO}_{4}$ was the sole component responsible for the observed particle growth (kinetic regime, $D_{\mathrm{p}} \ll 60 \mathrm{~nm}$ ):

$\mathrm{GR}=\frac{\gamma \times m_{\mathrm{v}} \times v_{\mathrm{mol}}}{2 \rho} \times c_{\mathrm{vapour}}$,

where $m_{\mathrm{V}}$ is the molecular mass of the vapour $\left(98 \mathrm{~g} \mathrm{~mole}^{-1}\right)$, $\rho$ is the density of the condensed vapour $\left(1.6 \mathrm{~g} \mathrm{~cm}^{-3}\right.$ assuming a $\mathrm{H}_{2} \mathrm{SO}_{4} / \mathrm{H}_{2} \mathrm{O}$ mixture of $68 \% \mathrm{H}_{2} \mathrm{SO}_{4}$ by weight at $273 \mathrm{~K}), v_{\mathrm{mol}}$ is the gas kinetic velocity of the vapour molecules (e.g. $242 \mathrm{~m} \mathrm{~s}^{-1}$ for $T=273 \mathrm{~K}$ ), $c_{\text {vapour }}$ is the gaseous $\mathrm{H}_{2} \mathrm{SO}_{4}$ concentration (mole $\mathrm{cm}^{-3}$ ) to be determined, and $\gamma$ is close to the $\mathrm{H}_{2} \mathrm{SO}_{4}$ accommodation coefficient (assumed to be around 1.0).

\section{Results}

\subsection{Data presentation}

During the first summer campaign in 2012 (comprising 66 observation days and 9500 raw spectra) we identified 19 events of NPF without clearly discernible particle growth (class II events according to Dal Maso et al., 2005). Growth rates could be reliably determined in eight class I or so-called "banana-type" events (Dal Maso et al., 2005). An overview of size-resolved aerosol data for the months January-March 2012 as well as a selected series of consecutive NPF events is presented in the Supplement (Figs. S1, S2) together with concurrently measured total $\mathrm{CP}$ concentrations, meteorological parameters, and the ionic composition of the bulk aerosol (SMPS data from both campaigns reported here are available at http://dx.doi.org/10.1594/PANGAEA. 845024 and auxiliary data can be found in the Supplement). Figure 1 focuses on a striking NPF event which happened on 27 January, where a simultaneous nucleation and Aitken mode growth was evident. This NPF event will be further discussed as case study in Sect. 4.1. Figure 2 shows a more detailed topographic view of this event on a linear $\mathrm{dN} / \mathrm{d} \log \mathrm{Dp}$ scale and is supplemented by corresponding profiles of lognormal distribution fits from selected time slices. In addition, a strikingly prolonged Aitken mode growth over about 3 days 

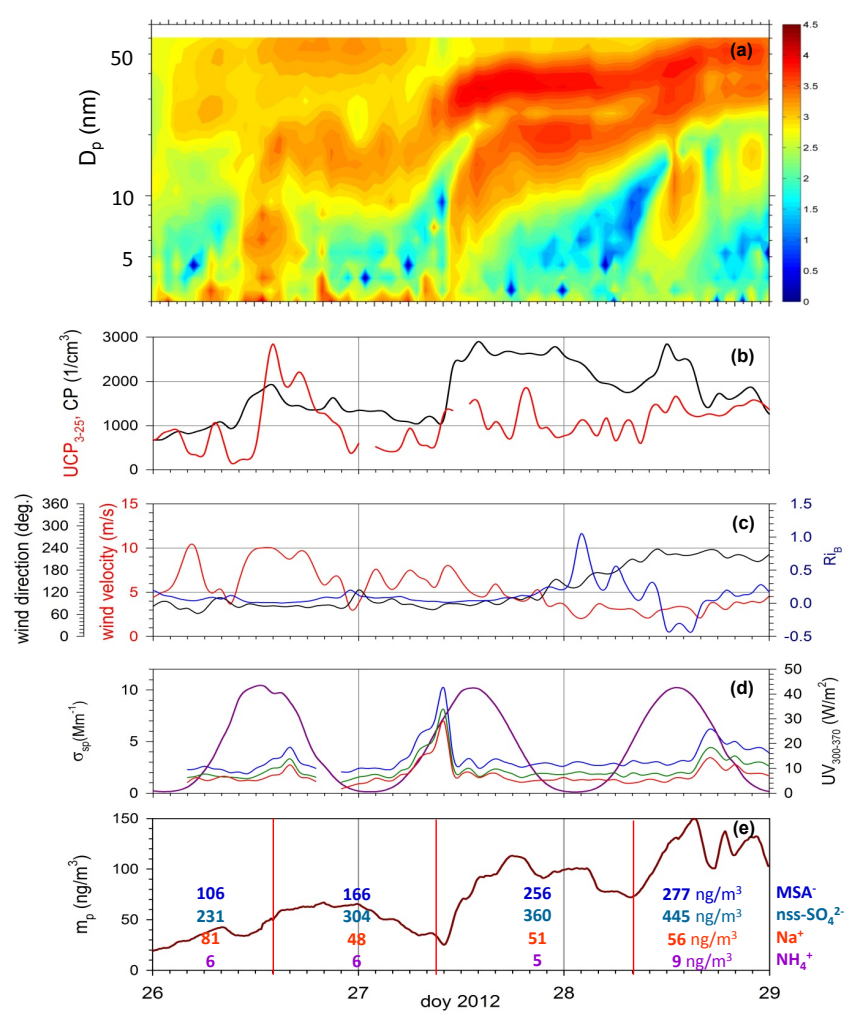

Figure 1. Time series of the measured particle size distribution $\mathrm{d} N / \mathrm{d} \log D_{\mathrm{p}}\left(\mathrm{cm}^{-3}\right)$ on a logarithmic scale (colour code to the right of the contour plot) of NPF events around 27 January 2012 showing a growing nucleation and Aitken mode (a), corresponding CP concentration (black line) and particle concentrations between 3 and $25 \mathrm{~nm}\left(\mathrm{UCP}_{3-25}\right.$, red line) (b), wind velocity (red line), wind direction (black line) and $R i_{\mathrm{B}}$ (blue line) (c), light scattering coefficients $\sigma_{\mathrm{sp}}$ at 450,550 , and $700 \mathrm{~nm}$ (blue, green and red lines) as well as UV radiation at wavelengths between 300 and $370 \mathrm{~nm}$ (purple line) (d), and aerosol mass $m_{\mathrm{p}}$ derived from SMPS measurements assuming a density of $1.8 \mathrm{~g} \mathrm{~cm}^{-3}$, as well as $\mathrm{MSA}^{-}, \mathrm{nss}_{-} \mathrm{SO}_{4}^{2-}, \mathrm{Na}^{+}$, and $\mathrm{NH}_{4}^{+}$concentrations derived from daily aerosol samples (red lines mark the time of filter exchange) (e).

$\left(\mathrm{GR}=0.3 \pm 0.05 \mathrm{~nm} \mathrm{~h}^{-1}\right)$ started on 1 March (doy 61) but without exhibiting a discernible nucleation mode (Supplement, Fig. S2). Particle concentrations in the nucleation mode were strongly correlated with total $\mathrm{CP}$ concentrations measured by the CPC 3022A (Supplement, Fig. S1b). A correlation of particle concentrations measured by the SMPS in the range between 5 and $64 \mathrm{~nm}$ with $\mathrm{CP}$ concentrations revealed a linear dependence (slope 0.992, $r^{2}=0.8$; see Fig. S3 in the Supplement), indicating that during summer $\mathrm{CP}$ number concentrations were dominated by nucleation and Aitken mode particles.

In contrast, the yield of NPF events during summer 2014 (February-April 2014, 85 observation days, 12240 raw spectra) was rather scanty: apart from 15 class II events, only two class I events could be discerned. A presentation of this
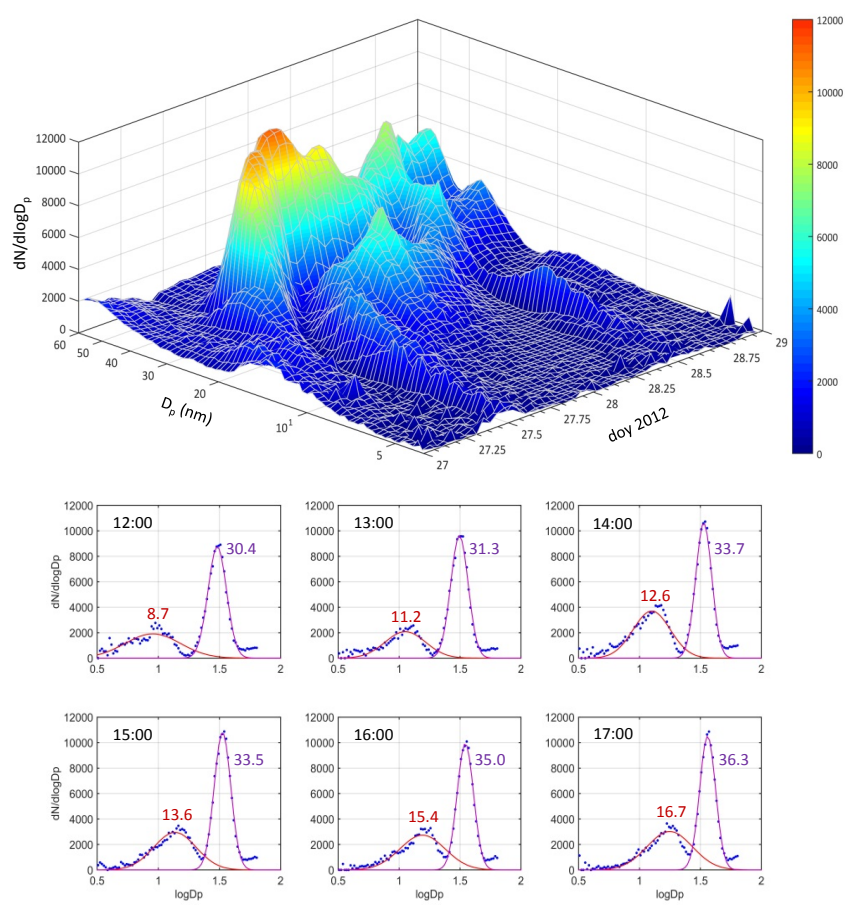

Figure 2. Detailed presentation of the NPF event around 27 January 2012 with a linear $\mathrm{d} N / \mathrm{d} \log D_{\mathrm{p}}\left(\mathrm{cm}^{-3}\right)$ scale as $z$ axis, based on hourly mean SMPS data recorded with 64 channel resolution. The lower panel shows exemplarily six log-normal distribution fits through size distributions measured on 27 January between 12:00 and 17:00 UTC. The mode mean diameters (in $\mathrm{nm}$ ) are noted next to the respective modal maxima.

time series can be found in the Supplement (Fig. S4). During winter (August and September 2014, 37.5 observation days, 5370 raw spectra), two certain class II events were evident (14/15 August and 21 September; Fig. 3). Figure 4 presents the mean particle size distribution during both winter events and for comparison for a typical non-event day (18 August 2014). Table 1 summarizes all evaluated class I events and lists the calculated GR, nucleation particle formation rates ( $\left.J_{3-25}\right)$ and the estimated $\mathrm{H}_{2} \mathrm{SO}_{4}$ concentration hypothetically needed for the respective GR.

\subsection{Meteorological aspects}

Regarding local meteorology, virtually all NPF events observed at NM occurred during southerly wind directions $\left(180 \pm 60^{\circ}\right)$ with wind velocities below $12 \mathrm{~m} \mathrm{~s}^{-1}$ (typically between 4 and $8 \mathrm{~m} \mathrm{~s}^{-1}$ ). Bright weather conditions usually prevailed with a cloud amount below 3 octans and a relative sunshine duration of around $(48 \pm 26) \%$ relating to clearsky conditions, except for three NPF events occurring during cloud-covered sky (25 February 2012, 8 and 9 March 2012). In all cases the local PBL was characterized by $R i_{\mathrm{B}}$ numbers $<0.25$, indicating turbulent flow and a well-mixed PBL. This was supported by HYSPLIT back trajectory anal- 

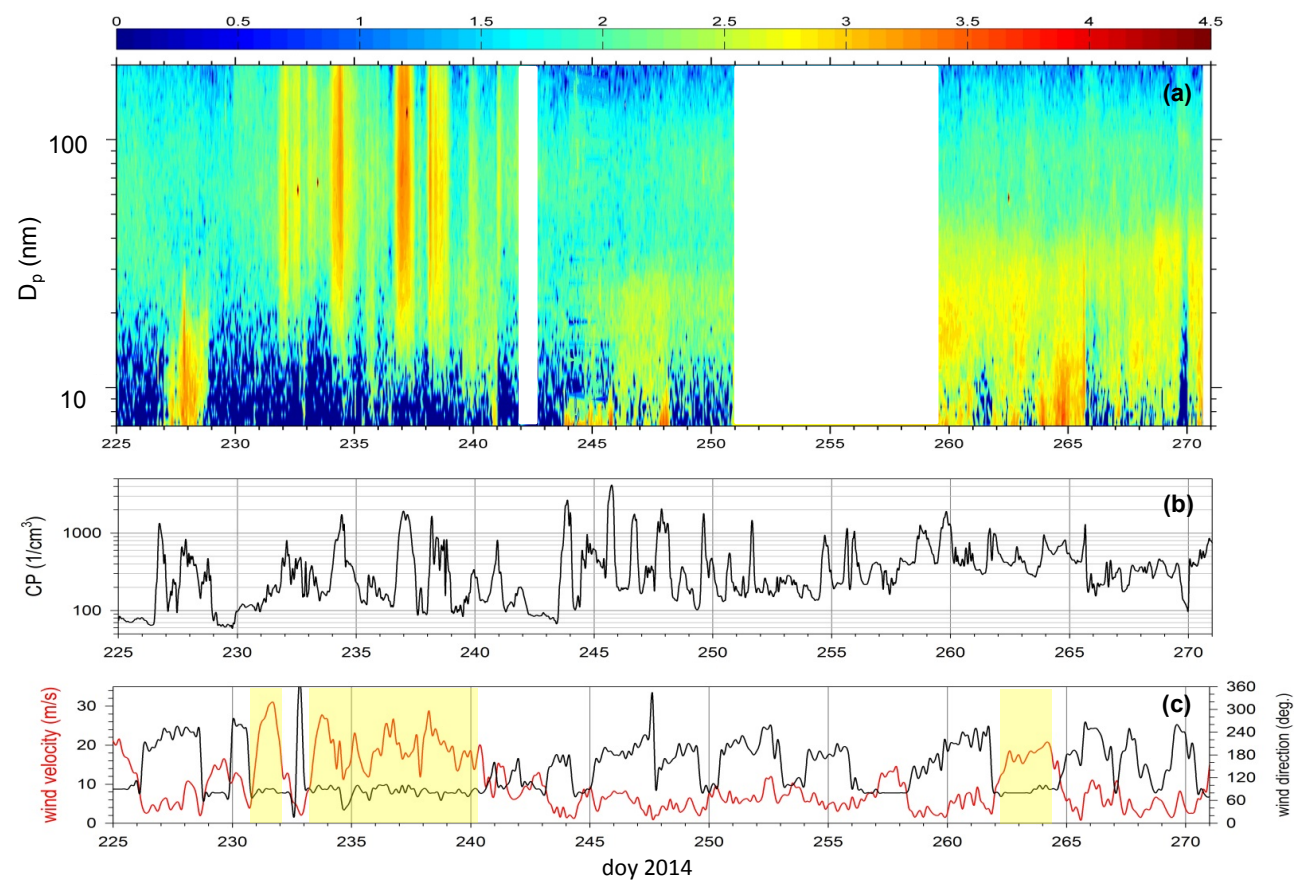

Figure 3. Time series of particle size distribution $\mathrm{d} N / \mathrm{d} \log D_{\mathrm{p}}\left(\mathrm{cm}^{-3}\right)$ measured during winter 2014 (12 August-27 September, logarithmic colour code to the right of the contour plot) (a), CP concentration (b), wind velocity (red line) and wind direction (black line) (c). The yellowish shaded areas in panel (c) mark stormy weather conditions associated with snow drift.

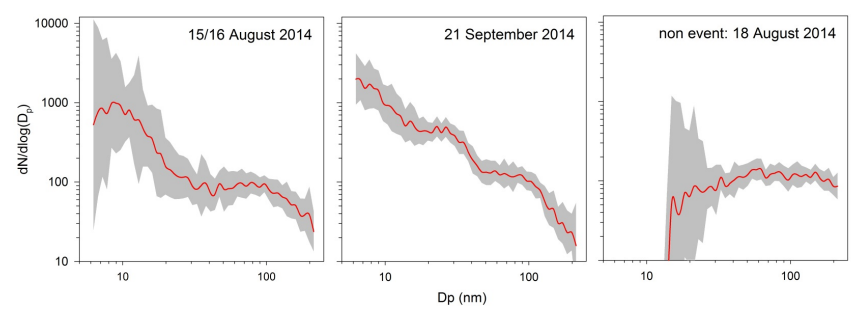

Figure 4. Mean size distribution (red line) and range of geometric standard deviation (grey envelope) during both winter particle nucleation events (15/16 August and 21 September 2014), as well as for a typical winter day without nucleation (18 August 2012).

yses indicating vertical mixing heights around $250 \mathrm{~m}$ (range: $100-600 \mathrm{~m}$ ) for the last $6 \mathrm{~h}$ before arrival at NM (5-day back trajectories for the most prominent nucleation events are presented in the Supplement, Fig. S5). Note, however, that mixing heights provided by HYSPLIT should be treated as a rough estimate, particularly regarding the Antarctica PBL due to the impact of katabatic winds and uncertain vertical wind components in general. The spatial extend of NPF events associated with appreciable particle growth could be estimated to be around $170 \pm 85 \mathrm{~km}$, taking into account the prevailing wind velocity (around $8 \pm 4 \mathrm{~m} \mathrm{~s}^{-1}$ ) and the confined NPF duration (around $6 \mathrm{~h}$; Table 1). Backward trajectories for NPF events revealed that frequently air masses originated from the marine boundary layer (MBL) of the
South Atlantic and then typically travelled along the Antarctic coastline up to 5 days before arrival at NM (Supplement, Fig. S5). A subsequent contact time of these trajectories with open water or sea ice was rather limited and often happened, if at all, just some hours before arrival at NM. During NPF events, trajectories mainly stayed below $1500 \mathrm{~m}$ above ground for the last $48 \mathrm{~h}$ before arrival at NM and mainly within the vertical mixing heights derived from HYSPLIT for the last $24 \mathrm{~h}$. It was only for the NPF event on 16 March 2012 that air masses clearly descended from the free troposphere (in this case $>2000 \mathrm{~m}$ above ground) in the last $24 \mathrm{~h}$ before arrival at NM. In summary, NPF-related trajectories indicate the importance of recent MBL air advection while the impact of descending air masses from the free troposphere seems to be rare. On the whole, trajectory analyses appeared somewhat equivocal in evaluating a rather local process like NPF, probably because of their particularly inherent spatial uncertainty in a region sparsely supported by meteorological data.

During summer, nucleation events showed a distinct diurnal cycle. They typically occurred in the second half of the day indicating a link to local photochemistry, though being sometimes delayed to the diurnal maximum of UV radiation by a few hours (Figs. 1, S2; Table 1). We did not discover a meaningful relation between UV irradiance and GR or particle formation rate. Table 2 presents a comparison of selected auxiliary parameters during NPF and nonevent days. In summary, NPF events tend to be accompanied by drier air (impact of southerly, continental advection), 
Table 2. Comparison of selected meteorological and aerosol light scattering parameters as well as ionic composition of the aerosol (all items in mean \pm SD) during days with NPF as characterized in Table 2 and non-event days. The comparison is restricted to the summer months (January-March).

\begin{tabular}{lrr}
\hline Parameter & NPF event & Non-event \\
\hline relative humidity $(\%)$ & $77.9 \pm 4.7$ & $82.4 \pm 5.1$ \\
$p\left(\mathrm{H}_{2} \mathrm{O}\right)(\mathrm{hPa})$ & $262 \pm 98$ & $281 \pm 100$ \\
$\sigma_{\mathrm{sp}}(450)\left(\mathrm{Mm}^{-1}\right)$ & $2.30 \pm 0.9$ & $3.20 \pm 2.2$ \\
$\sigma_{\mathrm{sp}}(550)\left(\mathrm{Mm}^{-1}\right)$ & $1.65 \pm 0.7$ & $2.50 \pm 1.9$ \\
$\sigma_{\mathrm{sp}}(700)\left(\mathrm{Mm}^{-1}\right)$ & $1.30 \pm 0.5$ & $2.00 \pm 1.5$ \\
$\alpha_{\mathrm{sc}}(450-550)$ & $1.8 \pm 0.2$ & $1.4 \pm 0.2$ \\
$\alpha_{\mathrm{sc}}(450-700)$ & $1.4 \pm 0.2$ & $1.3 \pm 0.2$ \\
$\alpha_{\mathrm{sc}}(550-700)$ & $1.2 \pm 0.2$ & $1.3 \pm 0.3$ \\
$\mathrm{MSA}^{-}\left(\mathrm{ng} \mathrm{m}^{-3}\right)$ & $109 \pm 54$ & $132 \pm 100$ \\
$\mathrm{nss}_{-} \mathrm{SO}_{4}^{2-}\left(\mathrm{ng} \mathrm{m}^{-3}\right)$ & $225 \pm 67$ & $274 \pm 160$ \\
$\mathrm{Na}^{+}\left(\mathrm{ng} \mathrm{m}^{-3}\right)$ & $45 \pm 19$ & $79 \pm 130$ \\
$\mathrm{NH}_{4}^{+}\left(\mathrm{ng} \mathrm{m}^{-3}\right)$ & $6.6 \pm 3$ & $12.5 \pm 11$ \\
\hline
\end{tabular}

lower aerosol light scattering coefficients (indicating lower particle surface area), and less aerosol mass. Winter events happened either within several hours around midnight or for more than a day (Fig. 3) and the measured maximum UV radiances were 4 and $18 \mathrm{~W} \mathrm{~m}^{-2}$ for the NPF events observed in August and September, respectively. Again, the respective 5day back trajectories documented a similar advection pattern as the summertime NPF events (Supplement, Fig. S6).

During stormy weather, occasionally enhanced particle concentrations appeared below $10 \mathrm{~nm}$. In this context, it is worth mentioning that Virkkula et al. (2007) and Asmi et al. (2010) observed at Aboa some nucleation events associated with high wind speeds and suggested ion production by fast moving ice crystals followed by subsequent ionmediated nucleation. As for NM the situation was somewhat unclear, because charged particle concentration data were not available and during stormy weather the overall electrostatic charge in combination with inherently critical electrical grounding conditions on ice may have provoked instrumental artefacts.

\section{Discussion}

\subsection{Case study}

A striking series of NPF occurred during 3 days, starting around noon on 26 January 2012 with a class II event (Fig. 1a), accompanied by an immediate increase of $\mathrm{UCP}_{3-25}$ concentration (Fig. 1b). Around noon, two size distribution maxima were discernible below $25 \mathrm{~nm}$, one around $6 \mathrm{~nm}$, the other between 15 and $20 \mathrm{~nm}$. While the first one disappeared after 16:00 UTC, the latter lingered on and started to grow between 07:00 and 14:00 UTC the next day $\left(\mathrm{GR}=1.9 \mathrm{~nm} \mathrm{~h}^{-1}\right.$,
Table 1), finally reaching a mode maximum around $50 \mathrm{~nm}$ after further growth during the afternoon of 28 January 2012. Coinciding with particle growth, the difference between $\mathrm{CP}$ and $\mathrm{UCP}_{3-25}$ concentrations steeply increased due to particle formation in the size range $D_{\mathrm{p}}>25 \mathrm{~nm}$. Starting at 11:00 UTC on 27 January 2012, a class I NPF event was observed showing particle growth from around 7 to $20 \mathrm{~nm}$ during the following $7 \mathrm{~h}$. Particle growth started again during the afternoon of 28 January 2012, eventually reaching a mode maximum around $25 \mathrm{~nm}$ (Figs. 1a, 2).

Interestingly, this class I NPF event commenced immediately after a striking peak in light scattering coefficients (Fig. 1d). Given that nephelometer measurements are primarily sensitive to particle concentrations within a size range comparable to the measuring wavelengths, this peak indicated simultaneously enhanced accumulation mode particle concentrations. One may argue that enhanced accumulation mode particles acted as additional CS and inhibited NPF, but this would be inconsistent to the observed distinct growth of the $15 \mathrm{~nm}$ nucleation mode from the previous day already starting at 07:00 UTC. Concerning meteorological and radiation conditions, all 3 days were virtually cloudless (as can also be deduced from the smooth and nearly sinusoidal $\mathrm{UV}_{300-370}$ signal; Fig. 1d) and southerly advection dominated. Trajectory analyses revealed that air masses had actually no contact with the MBL in at least the last $48 \mathrm{~h}$, but most of them originated in the MBL of the South Atlantic (Fig. 5) about 5 days before. This finding suggested a longrange transport of marine precursor gases associated with a delayed nucleation just before arrival at NM. Except for a short period around 02:00 UTC on 28 January $2012, R i_{\mathrm{B}}$ values indicated a well-mixed boundary layer (Fig. 1c).

From the measured size distribution spectra we calculated the total aerosol mass concentration $m_{\mathrm{p}}$ between 3 and $64 \mathrm{~nm}$, assuming a particle density of $1.8 \mathrm{~g} \mathrm{~cm}^{-3}$ (according to pure $\mathrm{H}_{2} \mathrm{SO}_{4}$ as an upper limit for dry sulfuric acid aerosol). The result is presented in Fig. 1e together with the ionic composition of the aerosol derived from our daily aerosol sampling. $\mathrm{MSA}^{-}$and nss- $\mathrm{SO}_{4}^{2-}$ mass concentrations increased throughout, while those of $\mathrm{Na}^{+}$(a tracer for sea salt aerosol) and $\mathrm{NH}_{4}^{+}$remained low (note that the time of the filter exchange is marked with vertical red lines). The stepwise increase of $m_{\mathrm{p}}$ appeared roughly comparable to the increase of nss- $\mathrm{SO}_{4}^{2-}$ mass concentrations from day to day. Note that this estimate presumes pure sulfuric acid aerosol and should thus be treated as the upper limit assessment. Furthermore, based on our measurements we cannot finally deduce whether $\mathrm{H}_{2} \mathrm{SO}_{4}$ vapour genuinely condensed on freshly formed nucleation mode particles or merely on aged background aerosol.

\subsection{Extent of particle growth}

In view of previous results from Antarctica (Asmi et al., 2010; Järvinen et al., 2013; Kyrö et al., 2013), NPF at NM 

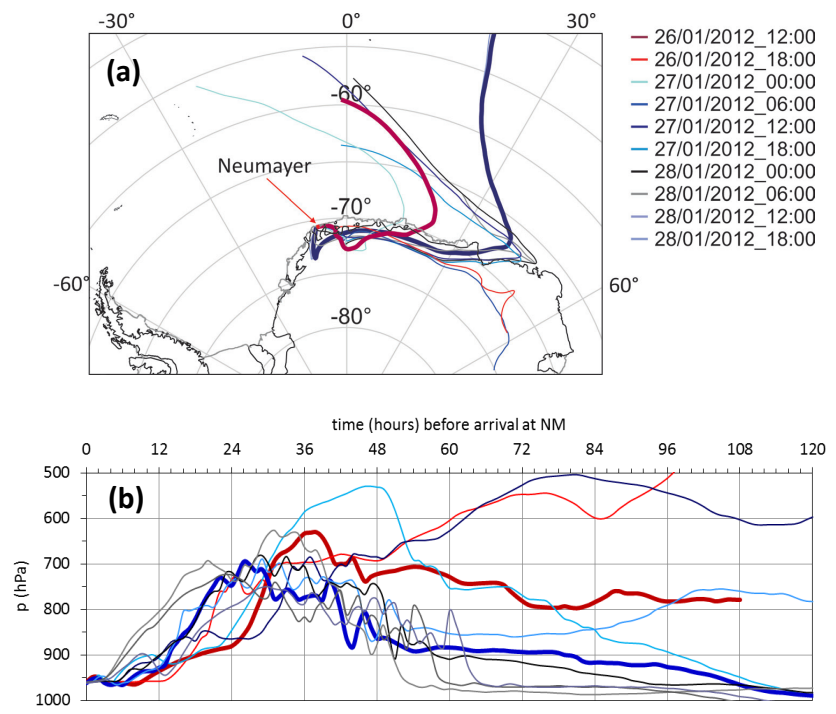

Figure 5. Five-day back trajectories based on 3-D wind fields for the period 26 January 2012-28 January 2012: horizontal advection pattern (a) and vertical profiles (b). Trajectories which arrived around the main NPF events (noon on 26 and 27 January 2012) are plotted as bold lines.

appeared notably less efficient. Particle growth was usually confined to the nucleation mode and only once extended into the Aitken mode (see case study described in Sect. 4.1). Consequently, this NPF event was the only one at NM where the growth of nucleated particles reached a size range potentially relevant for acting as $\mathrm{CCN}$. On the other hand, a persistent but not locally developed Aitken mode was often present during the polar day (Supplement Fig. S1) and after being absent in August reappeared in September (Fig. 3). Notwithstanding, some discrete events with strikingly high particle concentrations between 30 and $200 \mathrm{~nm}$ occurred in August exclusively under stormy weather (wind velocity around $20 \mathrm{~m} \mathrm{~s}^{-1}$; Fig. 3). Contemporaneously, $\mathrm{Na}^{+}$concentrations increased from background levels around $80 \mathrm{ng} \mathrm{m}^{-3}$ to values between 480 and $1010 \mathrm{ng} \mathrm{m}^{-3}$. According to impactor measurements conducted by Teinilä et al. (2014) in the year 2010 at NM, it is most likely that sub-micrometre sea salt aerosol also caused the latter peculiarities.

\subsection{Role of DMS-derived sulfuric acid and MSA}

Although the air mass advection pattern assessed by trajectory calculations turned out to be equivocal, the observed diurnal cycle of NPF and the ionic composition of the aerosol indicate that particle nucleation at NM was most probably induced by emissions of marine biogenic precursor gases (Yu and Luo, 2010). More precisely, photo-oxidation of phytoplankton-derived dimethyl sulfide (DMS) is in general the prominent photochemical process in the troposphere of coastal Antarctica (e.g. Minikin et al., 1998), yielding ultimately sulfuric acid $\left(\mathrm{H}_{2} \mathrm{SO}_{4}\right)$ and methane sulfonic acid
(MSA, $\mathrm{CH}_{3} \mathrm{SO}_{3} \mathrm{H}$ ). Nevertheless, and in agreement with results from other Antarctic sites (Järvinen et al., 2013; Kyrö et al., 2013), the $\mathrm{H}_{2} \mathrm{SO}_{4}$ concentrations needed for the observed growth rates should be at least an order of magnitude higher compared to available values actually observed in Antarctica: Jefferson et al. (1998) measured mean $\mathrm{H}_{2} \mathrm{SO}_{4}$ concentrations of around $1.6 \times 10^{6} \mathrm{molec} \mathrm{cm}^{-3}$ during the SCATE (Sulfur Chemistry in the Antarctic Troposphere Experiment) campaign at the Palmer Station (Antarctic Peninsula) in summer and at the South Pole during the ISCAT (Investigation of Sulfur Chemistry in the Antarctic Troposphere) 2000 campaign $\mathrm{H}_{2} \mathrm{SO}_{4}$ (MSA) concentrations of around $0.27 \times 10^{6}$ molec cm $\mathrm{cm}^{-3}\left(0.08 \times 10^{6} \mathrm{molec} \mathrm{cm}^{-3}\right)$ were detected in December (Mauldin III et al., 2004). Although the chemical composition of secondary aerosol during summer at NM was usually dominated by DMS-derived nss-SO ${ }_{4}^{2-}$ and MS (Weller and Lampert, 2008; Weller et al., 2011b), according to this estimate observed particle growth in the early stage should yet be controlled by other low volatile vapours.

\subsection{Possible role of $\mathrm{H}_{2} \mathrm{O}$ vapour, $\mathrm{NH}_{3}$, organic vapour, iodine oxide, and ions}

Theoretical and laboratory studies revealed that $\mathrm{H}_{2} \mathrm{O}$ molecules are important for early particle growth $(2-3 \mathrm{~nm})$ due to stabilization of the critical nucleus by $\mathrm{H}_{2} \mathrm{SO}_{4}$-hydrate formation, while further particle growth is dominated by $\mathrm{H}_{2} \mathrm{SO}_{4}$ or low volatile organic vapours (Nieminen et al., 2010; Zhang et al., 2012). These investigations indicated that under prevalent atmospheric conditions the nucleation rate might be correlated with relative humidity $(\mathrm{RH})$, depending on $\mathrm{NH}_{3}$ and organic vapour concentrations (Zhang et al., 2012). Concerning this point, our data were inconclusive: it seems, though in contrast to the above mentioned investigations, that NPF events sometimes occurred during RH decrease (Supplement, Fig. S2). But this apparent correlation was particularly due to the fact that we mainly observed NPF in the afternoon when increasing temperatures usually induced decreasing RH levels. In addition, a correlation between $\mathrm{H}_{2} \mathrm{O}$ vapour partial pressure (i.e. absolute humidity) and nucleation rates derived from Eq. (1) was absent.

Apart from $\mathrm{H}_{2} \mathrm{SO}_{4}$ and $\mathrm{H}_{2} \mathrm{O}$ vapour, gaseous precursors like $\mathrm{NH}_{3}$, organic vapours (notably organic amines), and inorganic iodine compounds (mainly iodine oxides) are known to be strongly involved in particle nucleation and particle growth (O'Dowd et al., 2002b; Kulmala et al., 2004b; Facchini et al., 2008a; McFiggans et al., 2010; Metzger et al., 2010; Benson et al., 2011; Dawson et al., 2012; Riccobono et al., 2012; Riipinen et al., 2012; Wang et al., 2013). As for $\mathrm{NH}_{3}$, previous thermodenuder measurements at $\mathrm{NM}$ indicated that biogenic secondary aerosol was likely an internal mixture of the acids $\mathrm{H}_{2} \mathrm{SO}_{4}$ and MSA partly neutralized by $\mathrm{NH}_{3}$ (Weller et al., 2011a). Actually, we observed $\mathrm{NH}_{4}^{+}$ concentrations at NM of around $10 \mathrm{ng} \mathrm{m}^{-3}$. Preliminary re- 
sults on the amount of water soluble organic carbon (WSOC, excluding MSA), determined from bulk filter samples taken during austral summer 2011 showed values between 5 and $35 \mathrm{ngC} \mathrm{m}^{-3}$ (method: solid phase extraction followed by TOC (total organic carbon) analysis; J. Lehmann, personal communication, 2015). Interestingly, $\mathrm{NH}_{4}^{+}$and WSOC concentrations appeared thus similar to values reported from Aboa (Asmi et al., 2010) where particle growth was more pronounced. At Aboa, biogenic emissions by nearby melting ponds were found to be a potential source for condensable vapour (Kyrö et al., 2013), while the surroundings of NM are completely ice covered throughout (apart from open water dependent on seasonal sea ice coverage) and the nearest insular rocky outcrops are more than $200 \mathrm{~km}$ away. One may speculate that marine primary organic aerosol was dominant at NM, linked with sea spray formation by bubble bursting (Facchini et al., 2008b), while at Aboa condensable organic vapour emissions from melting ponds were decisive.

From the mid-latitude European sites Roscoff and Mace Head there exists strong evidence for iodine-mediated NPF (O'Dowd et al., 2002b; McFiggans et al., 2010) and, in recent studies, a possible impact of IO (iodine oxide) on NPF in the Arctic (Allan et al., 2015) and particle number concentrations at Halley Station, Antarctica (Roscoe et al., 2015), were inferred. Concerning iodine compounds, in situ measurements by long-path Differential Optical Absorption Spectroscopy (LP-DOAS) conducted at Halley (Saiz-Lopez et al., 2007) as well as respective satellite observations (Schönhardt et al., 2012) revealed maximum IO concentration of some 5 pptv (volume parts per trillion) over Antarctic coastal regions around October. Such IO levels were comparable to coastal European sites like Roscoff and Mace Head (O'Dowd et al., 2002b; McFiggans et al., 2010). At NM, multi-axis (MAX) DOAS measurements using scattered skylight primarily provided IO column densities, which did not show a discernible seasonality (Frieß et al., 2010). Note that MAXDOAS measurements were only available during clear sky conditions and solar zenith angles $<85^{\circ}$ and were not available for the observed winter NPF events. Presuming that IO was restricted within the PBL (below $2 \mathrm{~km}$ ), comparable IO mixing ratios in the range of some pptv could be derived for $\mathrm{NM}$ in some cases, but this approach is actually highly uncertain (Frieß et al., 2001, 2010). Interestingly, at Dumont d'Urville (DDU), IO concentrations were found to be an order of magnitude lower indicating that halogen chemistry in general was probably promoted by the much larger sea ice extent of the Atlantic sector of Antarctica (Grilli et al., 2013). Considering the available laboratory, field and model results, it appears difficult to estimate the IO concentrations needed to provoke significant particle nucleation but it seems that several pptv of IO or OIO (iodine dioxide) would be necessary (Pechtl et al., 2006; Saiz-Lopez et al., 2012; Roscoe et al., 2015). In view of the minor importance of DMS photochemistry, however, we speculate that IO probably initiated the observed NPF at NM in late winter. The shape of both winter events and the fact that growth rates could not be determined indicated a local origin where particle size distribution developed during transport time to the measuring site (Kulmala et al., 2012).

At last, given that in our case particle formation rates $\mathrm{J}_{3-25}$ were generally below $0.1 \mathrm{~cm}^{-3} \mathrm{~s}^{-1}$, atmospheric ions could have significantly contributed to particle nucleation at NM (Almeida et al., 2013, Fig. 2 therein). In this regard, a modelling study by Yu and Luo (2010) demonstrated that NPF in coastal Antarctic regions can be reasonably described by ion-mediated $\mathrm{H}_{2} \mathrm{SO}_{4} / \mathrm{H}_{2} \mathrm{O}$ nucleation.

\section{Conclusions}

Based on our data we can only speculate about the prevailing nucleation mechanism at $\mathrm{NM}$, but our findings are essentially consistent with $\mathrm{H}_{2} \mathrm{SO}_{4} / \mathrm{NH}_{3} / \mathrm{H}_{2} \mathrm{O}$ ternary and/or $\mathrm{H}_{2} \mathrm{SO}_{4} / \mathrm{H}_{2} \mathrm{O}$ ion-mediated nucleation during summer. In contrast, the observed particle growth was governed by the availability of other yet not identified gaseous precursors, most probably low volatile organic compounds of marine origin. Due to the apparent deficit of the latter, particle growth was accordingly restricted within the nucleation mode and mostly did not extend to particle diameter ranges relevant for acting as cloud condensation nuclei. Given that particle growth in the early stage (i.e. within the nucleation mode) was governed by low volatile vapours other than $\mathrm{H}_{2} \mathrm{SO}_{4}$, another remaining crucial question is in which way was the finally sulfuric-acid-dominated secondary aerosol at NM ultimately generated? During summer, a potential role of iodine oxides in particle nucleation was unclear, while for the observed winter events these compounds could be potential candidates. But then, the even more pronounced deficit of condensable vapour due to depressed photochemical activity impeded particle growth beyond particle diameters of about $15 \mathrm{~nm}$

In conclusion, our investigations indicate three crucial points concerning NPF in Antarctica that are supposed to be addressed in future work. (i) Up to now, from this region only sparse and inadequate knowledge exists on organic aerosols, in particular secondary organic aerosol. Identification of the most important compounds, their origin and source strength is still fragmentary at best. (ii) IO concentrations should be measured year-round by in situ techniques in order to better assess their role in NPF and validate the respective satellite retrievals. (iii) The role of free tropospheric air in providing gaseous precursors for particle nucleation and growth within the PBL needs clarification. This point appeared especially important for continental Antarctica in view of the recently described NPF events observed at Dome C (Järvinen et al., 2013).

The Supplement related to this article is available online at doi:10.5194/acp-15-11399-2015-supplement. 
Acknowledgements. The authors would like to thank the technicians and scientists of the Neumayer overwintering teams of the years 2012 and 2013, whose outstanding commitment enabled continuous high quality measurements. R. Hillamo and K. Teinilä thank the Academy of Finland for the financial support (project ACPANT, decision no. 264375). Special thanks go to Kathrin Höppner, responsible for the Air Chemistry Observatory during the overwintering 2012, to Udo Frieß for beneficial discussions regarding $\mathrm{IO}$ concentrations at NM, and finally to Astrid Lampert for many fruitful suggestions. We are thankful to the NOAA Air Resources Laboratory for having made available the HYSPLIT trajectory calculation program as well as all input data files used.

Edited by: F. Yu

\section{References}

Allan, J. D., Williams, P. I., Najera, J., Whitehead, J. D., Flynn, M. J., Taylor, J. W., Liu, D., Darbyshire, E., Carpenter, L. J., Chance, R., Andrews, S. J., Hackenberg, S. C., and McFiggans, G.: Iodine observed in new particle formation events in the Arctic atmosphere during ACCACIA, Atmos. Chem. Phys., 15, 55995609, doi:10.5194/acp-15-5599-2015, 2015.

Almeida, J., Schobesberger, S., Kürten, A., Ortega, I. K., Kupiainen-Määttä, O., Praplan, A. P., Adamov, A., Amorim, A., Bianchi, F., Breitenlechner, M., David, A., Dommen, J., Donahue, N. M., Downard, A., Dunne, E. M., Duplissy, J., Ehrhart, S., Flagan, R. C., Franchin, A., Guida, R., Hakala, J., Hansel, A., Heinritzi, M., Henschel, H., Jokinen, T., Junninen, H., Kajos, M., Kangasluoma, J., Keskinen, H., Kupc, A., Kurtén, T., Kvashin, A. N., Laaksonen, A., Lehtipalo, K., Leiminger, M., Leppä, J., Loukonen, V., Makhmutov, V., Mathot, S., McGrath, M. J., Nieminen, T., Olenius, T., Onnela, A., Petäjä, T., Riccobono, F., Riipinen, I., Rissanen, M., Rondo, L., Ruuskanen, T., Santos, F. D., Sarnela, N., Schallhart, S., Schnitzhofer, R., Seinfeld, J. H., Simon, M., Sipilä, M., Stozhkov, Y., Stratmann, F., Tomé, A., Tröstl, J., Tsagkogeorgas, G., Vaattovaara, P., Viisanen, Y., Virtanen, A., Vrtala, A., Wagner, P. E., Weingartner, E., Wex, H., Williamson, C., Wimmer, D., Ye, P., Yli-Juuti, T., Carslaw, K. S., Kulmala, M., Curtius, J., Baltensperger, U., Worsnop, D. R., Vehkamäki, H., and Kirkby, J.: Molecular understanding of sulphuric acid-amine particle nucleation in the atmosphere, Nature, 502, 359-363, 2013.

Asmi, E., Frey, A., Virkkula, A., Ehn, M., Manninen, H. E., Timonen, H., Tolonen-Kivimäki, O., Aurela, M., Hillamo, R., and Kulmala, M.: Hygroscopicity and chemical composition of Antarctic sub-micrometre aerosol particles and observations of new particle formation, Atmos. Chem. Phys., 10, 4253-4271, doi:10.5194/acp-10-4253-2010, 2010.

Benson, D. R., Yu, J. H., Markovich, A., and Lee, S.-H.: Ternary homogeneous nucleation of $\mathrm{H}_{2} \mathrm{SO}_{4}, \mathrm{NH}_{3}$, and $\mathrm{H}_{2} \mathrm{O}$ under conditions relevant to the lower troposphere, Atmos. Chem. Phys., 11, 4755-4766, doi:10.5194/acp-11-4755-2011, 2011.

Boucher, O., Randall, D., Artaxo, P., Bretherton, C., Feingold, G., Forster, P., Kerminen, V.-M., Kondo, Y., Liao, H., Lohmann, U., Rasch, P., Satheesh, S. K., Sherwood, S., Stevens B., and Zhang, X. Y.: Clouds and Aerosols, in: Climate Change 2013: The Phys- ical Science Basis. Contribution of Working Group I to the Fifth Assessment Report of the Intergovernmental Panel on Climate Change, edited by: Stocker, T. F., Qin, D., Plattner, G.-K., Tignor, M., Allen, S. K., Boschung, J., Nauels, A., Xia, Y., Bex, V., and Midgley, P. M., Cambridge University Press, Cambridge, UK and New York, NY, USA, 2013.

Bzdek, B. and Johnston, M. V.: New Particle Formation and Growth in the Troposphere, Anal. Chem., 82, 7871-7878, doi:10.1021/ac100856j, 2010.

Carslaw, K. S., Lee, L. A., Reddington, C. L., Pringle, K. J., Rap, A., Forster, P. M., Mann, G. W., Spracklen, D. V., Woodhouse, M. T., Regayre, L. A., and Pierce, J. R.: Large contribution of natural aerosol to uncertainty in indirect forcing, Nature, 503, 67-71, doi:10.1038/nature12674, 2013.

Dal Maso, M., Kulmala, M., Riipinen, I., Wagner, R., Hussein, T., Aalto, P. P., and Lehtinen, E. J.: Formation and growth of fresh atmospheric aerosols: eight years of aerosol size distribution data from SMEAR II, Hyytiälä, Finland, Boreal Env. Res., 10, 323336, 2005.

Dawson, M. L., Varner, M. E., Perraud, V., Ezell, M. J., Gerber, R. B., and Finlayson-Pitts, B. J.: Simplified mechanism for new particle formation from methanesulfonic acid, amines, and water via experiments and ab initio calculations, P. Natl. Acad. Sci. USA, 109, 18719-18724, doi:10.1073/pnas.1211878109, 2012.

Facchini, M. C., Decesari, S., Rinaldi, M., Carbone, C., Finessi, E., Mircea, M., Fuzzi, S., Moretti, F., Tagliavini, E., Ceburnis, D., and O'Dowd, C. D.: Important Source of Marine Secondary Organic Aerosol from Biogenic Amines, Environ. Sci. Technol., 42, 9116-9121, 2008a.

Facchini, M. C., Rinaldi, M., Decesari, S., Carbone, C., Finessi, E., Mircea, M., Fuzzi, S., Ceburnis, D., Flanagan, R., Nilsson, E. D., de Leeuw, G., Martino, M., Woeltjen, J., and O'Dowd, C. D.: Primary submicron marine aerosol dominated by insoluble organic colloids and aggregates, Geophys. Res. Lett., 35, L17814, doi:10.1029/2008GL034210, 2008b.

Frieß, U., Wagner, T., Pundt, I., Pfeilsticker, K., and Platt, U.: Spectroscopic Measurements of Troposheric Iodine Oxide at Neumayer Station, Antarctica, Geophys. Res. Lett., 28, 1941-1944, doi:10.1029/2000GL012784, 2001.

Frieß, U., Deutschmann, T., Gilfedder, B. S., Weller, R., and Platt, U.: Iodine monoxide in the Antarctic snowpack, Atmos. Chem. Phys., 10, 2439-2456, doi:10.5194/acp-10-2439-2010, 2010.

Grilli, R., Legrand, M., Kukui, A., Méjean, G., Preunkert, S., and Romanini, D.: First investigations of $\mathrm{IO}, \mathrm{BrO}$, and $\mathrm{NO}_{2}$ summer atmospheric levels at a coastal East Antarctic site using modelocked cavity enhanced absorption spectroscopy, Geophys. Res. Lett., 40, 791-796, doi:10.1002/grl.50154, 2013.

Harris, J. M., Draxler, R. R., and Oltmans, S. J.: Trajectory model sensitivity to differences in input data and vertical transport method, J. Geophys. Res., 110, D14109, doi:10.1029/2004JD005750, 2005.

Haywood, J. and Boucher, O.: Estimates of the direct and indirect radiative forcing due to tropospheric aerosols: A review, Rev. Geophys., 38, 513-543, 2000.

Henze, D. K. and Seinfeld, J. H.: Global secondary organic aerosol from isoprene oxidation, Geophys. Res. Lett., 33, L09812, doi:10.1029/2006GL025976, 2006.

Humphries, R. S., Schofield, R., Keywood, M., Ward, J., Pierce, J. R., Gionfriddo, C. M., Tate, M., Krabbenhoft, D., Galbally, 
I. E., Molloy, S. B., Klekociuk, A., Johnston, P. V., Kreher, K., Thomas, A. J., Robinson, A. D., Harris, N. R. P., Johnson, R., and Wilson, S. R.: Boundary layer new particle formation over East Antarctic sea ice - possible Hg driven nucleation?, Atmos. Chem. Phys. Discuss., 15, 19477-19536, doi:10.5194/acpd-1519477-2015, 2015.

Ito, T.: Study of background aerosols in the Antarctic Troposphere, J. Atmos. Chem., 3, 69-91, 1985.

Ito, T.: Size distribution of Antarctic submicron aerosols, Tellus, 45B, 145-159, 1993.

Jaenicke, R., Dreiling, V., Lehmann, E., Koutsenoguii, P. K., and Stingl, J.: Condensation nuclei at the German Antarctic Station "Georg von Neumayer", Tellus, 44B, 311-317, 1992.

Järvinen, E., Virkkula, A., Nieminen, T., Aalto, P. P., Asmi, E., Lanconelli, C., Busetto, M., Lupi, A., Schioppo, R., Vitale, V., Mazzola, M., Petäjä, T., Kerminen, V.-M., and Kulmala, M.: Seasonal cycle and modal structure of particle number size distribution at Dome C, Antarctica, Atmos. Chem. Phys., 13, 7473-7487, doi:10.5194/acp-13-7473-2013, 2013.

Jefferson, A., Tanner, D. J., Eisele, F. L., Davis, D. D., Chen, G., Crawford, J., Huey, J. W., Torres, A. L., and Berresheim, H.: $\mathrm{OH}$ photochemistry and methane sulfonic acid formation in the coastal Antarctic boundary layer, J. Geophys. Res., 103, 16471656, 1998.

König-Langlo, G., King, J. C., and Pettré, P.: Climatology of the three coastal Antarctic stations Dumont d'Urville, Neumayer and Halley, J. Geophys. Res., 103, 10935-10946, 1998.

Koponen, I. K., Virkkula, A., Hillamo, R., Kerminen, V.-M., and Kulmala, M.: Number size distribution and concentrations of the continental summer aerosol in Queen Maud Land, Antarctica, J. Geophys. Res., 108, 4587, doi:10.1029/2003JD003614, 2003.

Korhonen, H., Carslaw, K. S., Spracklen, D. V., Mann, G. W., and Woodhouse, M. T.: Influence of oceanic dimethyl sulfide emissions on cloud condensation nuclei concentrations and seasonality over the remote Southern Hemisphere oceans: A global model study, J. Geophys. Res., 113, D15204, doi:10.1029/2007JD009718, 2008.

Kulmala, M., Vehkamäki, H., Petäjä, T., Dal Maso, M., Lauri, A., Kerminen, V.-M., Birmili, W., and McMurry, P. H.: Formation and growth rates of ultrafine atmospheric particles: a review of observations, Aerosol Sci., 35, 143-176, doi:10.1016/j.jaerosci.2003.10.003, 2004a.

Kulmala, M., Kerminen, V.-M., Anttila, T., Laaksonen, A., and O'Dowd, D.: Organic aerosol formation via sulphate cluster activation, J. Geophys. Res., 109, D04205, doi:10.1029/2003JD003961, 2004b.

Kulmala, M., Petäjä, T., Nieminen, T., Sipilä, M., Manninen, H. E., Lehtipalo, K., Dal Maso, M., Aalto, P. P., Junninen, H., Paasonen, P., Riipinen, I., Lehtinen, K. E. J., Laaksonen, A., and Kerminen, V.-M.: Measurements of the nucleation of atmospheric aerosol particles. Nature Protocols, 7, 1651-1667, doi:10.1038/nprot.2012.091, 2012.

Kyrö, E.-M., Kerminen, V.-M., Virkkula, A., Dal Maso, M., Parshintsev, J., Ruíz-Jimenez, J., Forsström, L., Manninen, H. E., Riekkola, M.-L., Heinonen, P., and Kulmala, M.: Antarctic new particle formation from continental biogenic precursors, Atmos. Chem. Phys., 13, 3527-3546, doi:10.5194/acp-13-3527-2013, 2013.
Leppä, J., Anttila, T., Kerminen, V.-M., Kulmala, M., and Lehtinen, K. E. J.: Atmospheric new particle formation: real and apparent growth of neutral and charged particles, Atmos. Chem. Phys., 11, 4939-4955, doi:10.5194/acp-11-4939-2011, 2011.

Mauldin III, R. L., Kosciuch, E., Henry, B., Eisele, F.L., Shetter, R., Lefer, B., Chen, G., Davis, D., Huey, G., and Tanner, D.: Measurements of $\mathrm{OH}, \mathrm{HO}_{2}+\mathrm{RO}_{2}, \mathrm{H}_{2} \mathrm{SO}_{4}$, and MSA at the South Pole during ISCAT 2000, Atmos. Environ., 38, 54235437, 2004.

McFiggans, G., Bale, C. S. E., Ball, S. M., Beames, J. M., Bloss, W. J., Carpenter, L. J., Dorsey, J., Dunk, R., Flynn, M. J., Furneaux, K. L., Gallagher, M. W., Heard, D. E., Hollingsworth, A. M., Hornsby, K., Ingham, T., Jones, C. E., Jones, R. L., Kramer, L. J., Langridge, J. M., Leblanc, C., LeCrane, J.-P., Lee, J. D., Leigh, R. J., Longley, I., Mahajan, A. S., Monks, P. S., Oetjen, H., Orr-Ewing, A. J., Plane, J. M. C., Potin, P., Shillings, A. J. L., Thomas, F., von Glasow, R., Wada, R., Whalley, L. K., and Whitehead, J. D.: Iodine-mediated coastal particle formation: an overview of the Reactive Halogens in the Marine Boundary Layer (RHaMBLe) Roscoff coastal study, Atmos. Chem. Phys., 10, 2975-2999, doi:10.5194/acp-10-2975-2010, 2010.

Metzger, A., Verheggen, B., Dommen, J., Duplissy, J., Prevot, A. S. H., Weingartner, E., Riipinen, I., Kulmala, M., Spracklen, D. V., Carslaw, K. S., and Baltensperger, U.: Evidence for the role of organics in aerosol particle formation under atmospheric conditions, P. Natl. Acad. Sci. USA, 107, 6646-6651, doi:10.1073/pnas.0911330107, 2010.

Minikin, A., Legrand, M., Hall, J., Wagenbach, D., Kleefeld, C., Wolff, E., Pasteur, E. C., and Ducroz, F.: Sulfur-containing species (sulfate and methanesulfonate) in coastal Antarctic aerosol and precipitation, J. Geophys. Res., 103, 10975-10990, 1998.

Nieminen, T., Lehtinen, K. E. J., and Kulmala, M.: Sub-10 nm particle growth by vapor condensation - effects of vapor molecule size and particle thermal speed, Atmos. Chem. Phys., 10, 9773 9779, doi:10.5194/acp-10-9773-2010, 2010.

O'Dowd, C. D. and de Leeuw, G.: Marine aerosol production: a review of the current knowledge, Phil. Trans. R. Soc. A, 365, 1753-1774, doi:10.1098/rsta.2007.2043, 2007.

O’Dowd, C. D., Hämeri, K., Mäkelä, J. M., Pirjola, L., Kulmala, M., Jennings, S. G., Berresheim, H., Hansson, H.-C., de Leeuw, G., Kunz, G. J., Allen, A. G., Hewitt, C. N., Jackson, A., Viisanen, Y., and Hoffmann, T.: A dedicated study of New Particle Formation and Fate in the Coastal Environment (PARFORCE): Overview of objectives and achievements. J. Geophys. Res., 107, 8108, doi:10.1029/2001JD000555, 2002a.

O’Dowd, C. D., Jimenez, J. L., Bahreini, R., Flagan, R. C., Seinfeld, J. H., Hämeri, K., Pirjola, L., Kulmala, M., Jennings, S. G., and Hoffmann, T.: Marine aerosol formation from biogenic iodine emissions, Nature, 417, 632-636, doi:10.1038/nature00775, 2002 b.

Park, J., Sakurai, H., Vollmers, K., and McMurry, P. H.: Aerosol size distributions measured at South Pole during ISCAT, Atmos. Environ., 38, 5493-5500, doi:10.1016/j.atmosenv.2002.12.001, 2004.

Pechtl, S., Lovejoy, E. R., Burkholder, J. B., and von Glasow, R.: Modeling the possible role of iodine oxides in atmospheric new particle formation, Atmos. Chem. Phys., 6, 505-523, doi:10.5194/acp-6-505-2006, 2006. 
Piel, C., Weller, R., Huke, M., and Wagenbach, D.: Atmospheric methane sulfonate and non-sea salt sulphate records at the EPICA deep-drilling site in Dronning Maud Land, Antarctica, J. Geophys. Res., 111, D03304, doi:10.1029/2005JD006213, 2006.

Ramanathan, V., Crutzen, P. J., Kiehl, J. T., and Rosenfeld, D.: Aerosols, Climate, and the Hydrological Cycle, Science, 294, 2119-2124, 2001.

Riccobono, F., Rondo, L., Sipilä, M., Barmet, P., Curtius, J., Dommen, J., Ehn, M., Ehrhart, S., Kulmala, M., Kürten, A., Mikkilä, J., Paasonen, P., Petäjä, T., Weingartner, E., and Baltensperger, U.: Contribution of sulfuric acid and oxidized organic compounds to particle formation and growth, Atmos. Chem. Phys., 12, 9427-9439, doi:10.5194/acp-12-9427-2012, 2012.

Riipinen, I., Yli-Juuti, T., Pierce, J. R., Petäjä, T., Worsnop, D. R., Kulmala, M., and Donahue, N. M.: The contribution of organics to atmospheric nanoparticle growth, Nat. Geosci., 5, 453-458, doi:10.1038/ngeo1499, 2012.

Roscoe, H. K., Jones, A. E., Brough, N., Weller, R., SaizLopez, A., Mahajan, A., Schoenhardt, A., Burrows, J. P., and Fleming, Z. L.: Particles and iodine compounds in coastal Antarctica, J. Geophys. Res. Atmos., 120, 7144-7156, doi:10.1002/2015JD023301, 2015.

Rosenfeld, D., Andreae, M. O., Asmi, A., Chin, M., de Leeuw, G., Donovan, D. P., Kahn, R., Kinne, S., Kivekäs, N., Kulmala, M., Lau, W., Schmidt, K. S., Suni, T., Wagner, T., Wild, M., and Quaas, J.: Global observations of aerosol-cloudprecipitation-climate interactions, Rev. Geophys., 52, 750-808, doi:10.1002/2013RG000441, 2014.

Saiz-Lopez, A., Mahajan, A. S., Salmon, R. A., Bauguitte, J.-B., Jones, A. E., Roscoe, H. K., and Plane, J. M. C.: Boundary Layer Halogens in Coastal Antarctica, Science, 317, 348-351, doi:10.1126/science.1141408, 2007.

Saiz-Lopez, A., Plane, J. M. C., Baker, A. R., Carpenter, L. J., von Glasow, R., Gómez Martin, J. C., McFiggans, G., and Saunders, R. W.: Atmospheric Chemistry of Iodine, Chem. Rev., 112, 1773-1804, doi:10.1021/cr200029u, 2012.

Schönhardt, A., Begoin, M., Richter, A., Wittrock, F., Kaleschke, L., Gómez Martín, J. C., and Burrows, J. P.: Simultaneous satellite observations of IO and BrO over Antarctica, Atmos. Chem. Phys., 12, 6565-6580, doi:10.5194/acp-12-6565-2012, 2012.

Spracklen, D. V., Carslaw, K. S., Kulmala, M., Kerminen, V.-M., Mann, G. W., and Sihto, S.-L.: The contribution of boundary layer nucleation events to total particle concentrations on regional and global scales, Atmos. Chem. Phys., 6, 5631-5648, doi:10.5194/acp-6-5631-2006, 2006.

Spracklen, D. V., Carslaw, K. S., Kulmala, M., Kerminen, V.-M., Sihto, S.-L., Riipinen, I., Merikanto, J., Mann, G. W., Chipperfield, M. P., Wiedensohler, A., Birmili, W., and Lihavainen, H.: Contribution of particle formation to global cloud condensation nuclei concentrations, Geophys. Res. Lett., 35, L06808, doi:10.1029/2007GL033038, 2008.

Stohl, A.: Computation, accuracy and applications of trajectories a review and bibliography, Atmos. Environ., 32, 947-966, 1998.

Stull, R. B.: An Introduction to Boundary Layer Meteorology, Kluwer Academic Publishers, Dordrecht, the Netherlands, 175$180,1988$.
Teinilä, K., Frey, A., Hillamo, R., Tülp, H. C., and Weller, R.: A study of the sea-salt chemistry using size-segregated aerosol measurements at coastal Antarctic station Neumayer, Atmos. Environ., 96, 11-19, 2014.

Virkkula, A., Hirsikko, A., Vana, M., Aalto, P. P., Hillamo, R., and Kulmala, M.: Charged particle size distributions and analysis of particle formation events at the Finnish Antarctic research station Abao, Boreal Environ. Res., 12, 397-408, 2007.

Virkkula, A., Backman, J., Aalto, P. P., Hulkkonen, M., Riuttanen, L., Nieminen, T., dal Maso, M., Sogacheva, L., de Leeuw, G., and Kulmala, M.: Seasonal cycle, size dependencies, and source analyses of aerosol optical properties at the SMEAR II measurement station in Hyytiälä, Finland, Atmos. Chem. Phys., 11, 4445-4468, doi:10.5194/acp-11-4445-2011, 2011.

Wang, J., McGraw, R. L., and Kuang, C.: Growth of atmospheric nano-particles by heterogeneous nucleation of organic vapor, Atmos. Chem. Phys., 13, 6523-6531, doi:10.5194/acp-13-65232013, 2013.

Wang, S. C. and Flagan, R. C.: Scanning Electrical Mobility Spectrometer, Aerosol Sci. Technol., 13, 230-240, 1990.

Weller, R. and Lampert, A.: Optical properties and sulfate scattering efficiency of boundary layer aerosol at coastal Neumayer Station, Antarctica, J. Geophys. Res., 113, D16208, doi:10.1029/2008JD009962, 2008.

Weller, R., Minikin, A., Wagenbach, D., and Dreiling, V.: Characterization of the inter-annual, seasonal, and diurnal variations of condensation particle concentrations at Neumayer, Antarctica, Atmos. Chem. Phys., 11, 13243-13257, doi:10.5194/acp11-13243-2011, 2011a.

Weller, R., Wagenbach, D, Legrand, M., Elsässer, C., Tian-Kunze, X., and König-Langlo, G.: Continuous 25-years aerosol records at coastal Antarctica - 1: inter-annual variability of ionic compounds and links to climate indices, Tellus, 63B, 901-919, doi:10.1111/j.1600-0889.2011.00542.x, 2011b.

Weller, R., Levin, I., Schmithüsen, D., Nachbar, M., Asseng, J., and Wagenbach, D.: On the variability of atmospheric ${ }^{222} \mathrm{Rn}$ activity concentrations measured at Neumayer, coastal Antarctica, Atmos. Chem. Phys., 14, 3843-3853, doi:10.5194/acp-14-38432014, 2014.

Yli-Juuti, T., Nieminen, T., Hirsikko, A., Aalto, P. P., Asmi, E., Hõrrak, U., Manninen, H. E., Patokoski, J., Dal Maso, M., Petäjä, T., Rinne, J., Kulmala, M., and Riipinen, I.: Growth rates of nucleation mode particles in Hyytiälä during 20032009: variation with particle size, season, data analysis method and ambient conditions, Atmos. Chem. Phys., 11, 12865-12886, doi:10.5194/acp-11-12865-2011, 2011.

Yu, F. and Luo, G.: Oceanic Dimethyl Sulfide Emission and New Particle Formation around the Coast of Antarctica: A Modeling Study of Seasonal Variations and Comparison with Measurements, Atmosphere, 1, 34-50, doi:10.3390/atmos1010034, 2010.

Zhang, R., Khalizov, A., Wang, L., Hu, M., and Xu, W.: Nucleation and Growth of Nanoparticles in the Atmosphere, Chem. Rev., 112, 1957-2011, doi:10.1021/cr2001756, 2012. 